4. Austrian R, Gold J 1964 Pneumococcal bacteremia with especial reference to bacteremic pneumococcal pneumonia. Ann Intern Med 60:759

5. Baker PJ, Amsbough DF, Stashak PW, et al 1981 Regulation of the antibody response to pneumococcal polysaccharide by thymus-derived cells. Rev Infect Dis 3:332

6. Barrett-Connor E 1971 Bacterial infection and sickle cell anemia: an analysis of 250 infections in 16 patients and a review of the literature. Medicine $50: 97$

7. Barrett DJ, Ammann AJ 1981 Pneumococcal vaccine in sickle cell disease: IgG and IgM antibody response. Rev Infect Dis 3:S179

8. Barrett DJ, Ammann AJ, Stenmark S, Wara DW 1980 Immunoglobulin G and $M$ antibodies to pneumococcal polysaccharides detected by enzymelinked immunosorbent assay. Infect Immun 27:411

9. Borgono JM, McLean AA, Vella PP, et al 1978 Vaccination and revaccination with polyvalent pneumococcal polysaccharide vaccines in adults and infants. Proc Soc Exp Biol Med 157:148

10. Braley-Mullen H 1980 Direct demonstration of specific suppressor T-cells in mice tolerant to Type III and pneumococcal polysaccharide. Two-step requirement for development of detectable suppressor cells. J Immunol 125:1849

11. Cowan MJ, Ammann AJ, Wara DW, et al 1978 Pneumococcal polysaccharide immunization in infants and children. Pediatrics 62:721

12. Giebink GS, Le CT, Spika JS 1981 Summarized vs. type-specific analysis of antibody to pneumococcal capsular polysaccharides. Rev Infect Dis 3:S43

13. Klein JO 1981 The epidemiology of pneumococcal disease in infants and children. Rev Infect Dis 3:246

14. Landesman SH, Schiffman G 1981 Assessment of the antibody response to pneumococcal vaccine in high-risk populations. Rev Infect Dis 3:S180
15. Makela PH, Herva E, Sibakov M, et al 1980 Pneumococcal vaccine and otitis media. Lancet 1:547

16. Powars DR 1975 Natural history of sickle cell disease-the first ten years. Semin Hematol 12:267

17. Rytel MW 1982 Pneumococcal infections and pneumococcal vaccine: an update. Infect Contr 3:295

18. Schiffman G, Douglas RM, Bonner MJ, et al 1980 A radioimmunoassay for immunologic phenomena in pneumococcal disease and for the antibody response to pneumococcal vaccines. I. Method for the radioimmunoassay of anticapsular antibodies and comparison with other techniques. J Immunol Methods 33:133

19. Sell SH, Wright PF, Vaughn WK, et al 1981 Clinical studies of pneumococcal vaccines in infants. I. Reactogenicity and immunogenicity of two polyvalent polysaccharide vaccines. Rev Infect Dis 3:S97

20. Siber GR, Ransil BJ 1983 Methods for the analysis of antibody responses to vaccines or other immune stimuli. Methods Enzymol 93:4

21. Teele DW, Klein JO, Bratton L, et al 1981 Use of pneumococcal vaccine for prevention of recurrent acute otitis media in infants in Boston. Rev Infect Dis 3:S113

22. Ward J 1981 Antibiotic-resistant Streptococcus pneumoniae: clinical and epidemiological aspects. Rev Infect Dis 3:254

23. Weibel RE, Vella PP, McLean AA, et al 1977 Studies in human subjects of polyvalent pneumococcal vaccines. Proc Soc Exp Biol Med 156:144

24. Zar JH 1974 Biostatistical Analysis. Prentice-Hall, Inc, Englewood Cliffs, NJ

25. Ziehelboin S, Somasy A 1981 Multiple antibiotic resistance in South African strains of Streptococcus pneumoniae: mechanism of resistance to $\beta$-lactam antibiotics. Rev Infect Dis 3:267

\title{
Maternal Smoking Increases Xenobiotic Metabolism in Placenta but Not Umbilical Vein Endothelium
}

\author{
DAVID K. MANCHESTER, NATALIE B. PARKER, AND C. MICHAEL BOWMAN \\ Departments of Pediatrics and Pharmacology, University of Colorado School of Medicine, \\ Denver, Colorado 80262
}

\begin{abstract}
It is unclear whether placental xenobiotic metabolism can protect the human conceptus. In particular, the role of placental metabolism of toxic components of cigarette smoke such as polycyclic aromatic hydrocarbons (PAHs) is poorly understood. We hypothesized that increased aryl hydrocarbon hydroxylase (AHH) activity observed in placentas from smokers might help clear PAHs from maternal circulation and thereby prevent transplacental induction of AHH by PAHs. Our studies of AHH activity in human placentas and umbilical vein endothelium support this premise. While AHH activity was significantly increased in placentas from smokers compared with activity in placentas from nonsmokers, AHH activity in
\end{abstract}

Received August 10, 1983; accepted March 13, 1984

Address reprint requests to David Manchester, Department of Pediatrics, B-160, University of Colorado Health Sciences Center, 4200 E. Ninth Avenue, Denver, CO 80262 .

C. M. B. is a Clinician Scientist Awardee of the American Heart Association and recipient of a Faculty Development Award from the University of Colorado. This work was supported by grants from the American and Colorado Heart Associations, the University of Colorado, and National Institutes of Health Grant HD 12936. The protocol for this study was reviewed and approved by the Human Subjects Committees at University Hospital and Rose Medical Center, Denver, $\mathrm{CO}$. umbilical vein endothelium from these same pregnancies was unaffected by maternal smoking and remained low. In order to confirm that AHH present in endothelium was inducible, we also demonstrated dose-dependent increases in AHH activity in primary cultures of human umbilical vein endothelial cells exposed to PAHs. These findings may indicate first pass protection of the fetus by placental xenobiotic metabolism, or that endogenous factors suppress AHH induction in the fetus but not placenta. (Pediatr Res 18:1071-1075, 1984)

\section{Abbreviations}

AHH, aryl hydrocarbon hydroxylase

PAH, polycyclic aromatic hydrocarbon

HEPES, 4-(2-hydroxyethyl)-1-piperazineethanesulfonic acid

Maternal cigarette smoking increases risks for spontaneous abortion, premature delivery, and fetal growth retardation and 
may contribute to the development of certain birth defects (4, 16, 17). Although complex mixtures of chemicals contained in cigarette smoke have been described, little is known about the mechanisms by which these compounds may be embryopathic or about how the human conceptus can be protected from such chemical toxicity.

In order to approach these problems, we have been studying the effects of maternal smoking on xenobiotic metabolism in human placenta, concentrating on $\mathrm{AHH}$, a cytochrome P-450 monooxygenase system which increases its activity when mothers smoke $(14,20,24,29,30)$. AHH catalyzes the first step in the metabolism of several of the toxins absorbed from cigarette smoke including PAHs. These compounds, which are concentrated in cigarette smoke, have been found to be carcinogenic, mutagenic, and teratogenic in animals (5). The consequences of increased placental $\mathrm{AHH}$ activity in response to maternal smoking are unknown. On the one hand, microsomes from placentas from smokers have been shown to metabolize certain PAHs to mutagenic products in vitro (15). On the other hand, $\mathrm{AHH}$ participates in the clearance of toxins such as PAHs in vivo (18, 23 ), and increased placental activity may reduce levels of toxic PAHs in fetal tissues. Hence, increased placental AHH, coupled with a toxic load of PAHs from maternal smoking, could theoretically protect or endanger the developing fetus.

Because we are unable to measure placental clearance of PAHs directly in humans, we decided to approach the question of the role of placental PAH metabolism indirectly by comparing effects of cigarette smoking on placenta and a fetal tissue immediately distal to it, umbilical vein endothelium. We hypothesized that if increased placental AHH activity were involved in effectively decreasing levels of PAHs in distal tissues, then we would expect distal tissues to be less affected than the placenta by maternal cigarette smoke. We used $\mathrm{AHH}$ activity itself as a measure of PAH exposures and measured activity in placentas and umbilical vein endothelium from smoking and nonsmoking women. We report that while $\mathrm{AHH}$ activity in placenta is markedly increased by maternal cigarette smoking, activity in umbilical vein endothelium is not.

\section{MATERIALS AND METHODS}

Procurement of tissues. Placentas were collected at the time of delivery. Several representative samples of villous tissue were immediately removed and frozen at $-70^{\circ} \mathrm{C}$. Umbilical cords were removed and refrigerated no longer than $8 \mathrm{~h}$ prior to use. Cords were used only if they contained untraumatized segments greater than $18 \mathrm{~cm}$ in length.

Maternal smoking was determined by review of medical records and personal interview. Women were considered to be smokers if they used cigarettes daily up to admission for delivery. Nonsmokers had not used cigarettes at all during the pregnancy. Pregnancies were uncomplicated and mothers received no medications other than analgesics and anesthetics during labor. All pregnancies studied delivered at term (38-42 wk).

Isolation of endothelial cells. All cords were studied on the day of delivery and endothelial cells from individual cords were treated separately. The umbilical veins were r.nnulated with straight plastic tubing connectors (Cobe Laboratories, Lakewood, $\mathrm{CO}$ ) attached to three-way stopcocks and rinsed with $0.9 \%$ saline or with calcium- and magnesium-free Puck's Saline G until free of blood. A solution of HEPES-buffered (2.5 mM, pH 7.4) tissue culture medium (M199, Gibco, Grand Island, NY) containing $0.4 \mathrm{mg} / \mathrm{ml}$ collagenase (Worthington, Freehold, NJ) was then instilled with a syringe, the distal stopcock was closed, and the cord was incubated at $37^{\circ} \mathrm{C}$ for $15 \mathrm{~min}$. Following incubation, the solution containing endothelial cells was removed from the vein and the collagenase was inactivated by addition of an equal volume of tissue culture medium containing $20 \%$ fetal bovine serum (Biocell, Carson, CA).
Culture and identification of endothelial cells. Endothelial cells were cultured from single umbilical cords according to the methods of Gimbrone et al. (8). Cells were harvested as described above, washed in calcium- and magnesium-free Puck's Saline G, and resuspended in complete growth medium (M199) containing HEPES ( $\mathrm{pH} 7.4,25 \mathrm{mM}$ ), thymidine $\left(10^{-5} \mathrm{M}\right.$ ), antibiotics (penicillin, 100 units $/ \mathrm{ml}$; streptomycin, $100 \mu \mathrm{g} / \mathrm{ml}$; amphotericin $\mathrm{B}$, $0.25 \mu \mathrm{g} / \mathrm{ml}$ from Gibco; and gentamicin, $40 \mu \mathrm{g} / \mathrm{ml}$ from Schering, Kenilworth, NJ) and $20 \%$ fetal bovine serum. Suspended cells were cultured in $25-\mathrm{cm}^{2}$ flasks at $37^{\circ} \mathrm{C}$ in humidified room air containing $5 \% \mathrm{CO}_{2}$. Medium was replaced after $24 \mathrm{~h}$ and the remaining adherent cells were cultured until confluent (10 to 14 days) with media replacement twice weekly.

The identity of these cells as endothelial cells was confirmed by their cobblestone monolayer morphology when viewed by phase contrast microscopy $(8,13)$ and by the presence of factor VIII antigen detected by indirect immunofluorescence microscopy $(11,12)$.

Measurement of AHH activity. AHH activity was measured in placental microsomes as activity toward benzo $(a)$ pyrene according to the procedure described by Vaught et al. (29). Within 3 days of delivery, microsomes were prepared from homogenates of the frozen placental samples as previously described (20). Metabolites of benzo( $a$ ) pyrene were quantitatively estimated by comparing their relative fluorescence with that of a standard 3OH-benzo $(a)$ pyrene solution (a gift from Dr. Leland Chung, University of Colorado, Boulder) in a Perkin-Elmer model 203 fluorescence spectrophotometer. Activity was expressed as picomoles phenolic benzo $(a)$ pyrene metabolites formed $/ \mathrm{min} / \mathrm{mg}$ protein. Protein was measured by the method of Lowry et al. (19).

Umbilical vein endothelial cells were harvested as described above and washed in $0.05 \mathrm{M}$ Tris- $\mathrm{HCl}$ buffer, $\mathrm{pH} 8.5$, containing $3 \mathrm{mM} \mathrm{MgCl}$ and $0.2 \mathrm{M}$ sucrose. They were then resuspended in $1 \mathrm{ml}$ of the same buffer containing an NADPH-generating system. Final concentrations of cofactors were $1 \mathrm{mM}$ NADP, 10 $\mathrm{mM}$ glucose 6-phosphate, and 2 units/ml glucose 6-phosphate dehydrogenase. The reaction mixtures in $15-\mathrm{ml}$ screw-top tubes were placed in a $37^{\circ} \mathrm{C}$ shaking water bath (Dubnoff) and benzo $(a)$ pryene (Aldrich, Milwaukee, WI) was added in acetone $(50 \mu \mathrm{l})$ to a final concentration of $100 \mu \mathrm{M}$. These mixtures were incubated for $16 \mathrm{~h}$ and the reaction then was stopped by addition of $4 \mathrm{ml}$ acetone:hexane (1:3). The phenolic products of benzo $(a)$ pyrene metabolism were extracted and measured according to the procedure of Gurtoo et al. (9) again using 3-OHbenzo( $a$ pyrene as standard. Activity was expressed as picomoles metabolites formed in $16 \mathrm{~h} / \mu \mathrm{g}$ DNA. DNA was measured according to the method described by Paigen et al. (25). Cells harvested from individual umbilical veins were incubated for 16 $\mathrm{h}$ in order to get sufficient reaction products to avoid having to pool cells from different individuals in order to detect activity. We validated this approach by demonstrating that activity measured after $16 \mathrm{~h}$ was dependent upon cell protein and NADPH concentration. In addition, we compared AHH activity in intact cells with that observed in cells sonicated prior to incubation. Activities were comparable in these preparations, indicating that induction, which requires intact cells, had not occurred.

AHH in cultured endothelial cells. Confluent cultures of umbilical vein endothelial cells (more than $90 \%$ pure) were refed with complete growth medium containing known inducers of AHH activity. 3-Methylcholanthrene (1 $\mu \mathrm{M}$, Sigma, St. Louis, MO), $\beta$-naphthoflavone (10 $\mu \mathrm{M}$, Aldrich) or vehicle $(5 \mu \mathrm{l}$, acetone) was added and the cells incubated for $24 \mathrm{~h}$ at $37^{\circ} \mathrm{C}$ in $5 \%$ $\mathrm{CO}_{2}$ in air. Control and treated cells from the same cord were incubated in parallel. After $24 \mathrm{~h}$ the endothelial cells were harvested by treatment with trypsin $(0.05 \%)$-EDTA $(0.02 \%$, Gibco), washed, and resuspended in the Tris:sucrose: $\mathrm{MgCl}_{2}$ buffer described above. AHH activity was determined as activity toward benzo $(a)$ pyrene in reaction mixtures containing 2-3 $\times$ 


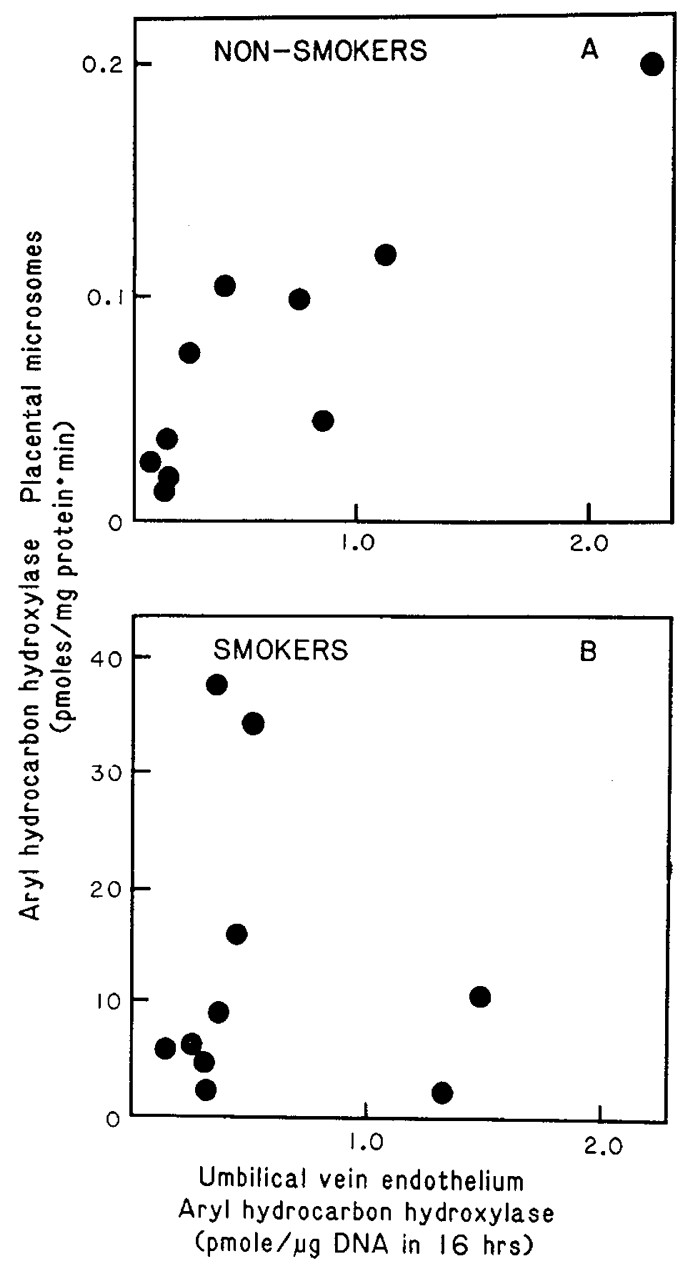

Fig. 1. AHH activities in placental microsomes and umbilical vein endothelium. Placentas were collected from 10 nonsmokers and 10 smokers. AHH activity was measured in placental microsomes and in
$10^{6}$ cells by the assay of Gurtoo et al. (9) as described above. Cells were incubated for $30 \mathrm{~min}$ and $\mathrm{AHH}$ activity is expressed as picomoles phenolic metabolites formed $/ 10^{6}$ cells. Cell counts were determined microscopically.

\section{RESULTS}

AHH activities in placenta and umbilical vein endothelium. We compared placental and umbilical vein endothelial cell AHH activities in material from 10 smoking and 10 nonsmoking women. AHH activity in cells from umbilical veins correlated well with $\mathrm{AHH}$ activity in placental microsomes from the same individuals when mothers did not smoke $(r=0.823, p<0.01$; Fig. $1 \mathrm{~A}$ ), consistent with the fact that placenta and umbilical vein both express fetal genotype. However, when mothers smoked, AHH activity in placental microsomes was much higher and the correlation with endothelial AHH activity was lost $(r=$ $-0.06, p=$ NS Fig. $1 B$ ). Comparison of mean AHH activities (Fig. 2) indicated that while maternal cigarette smoking was associated with significantly higher $(p<0.01 ; t$ test) AHH activity in placental microsomes, it had no effect on AHH activity in umbilical vein endothelium.

Induction of $\mathrm{AHH}$ in cultured endothelial cells. Since maternal smoking did not alter $\mathrm{AHH}$ activity in umbilical vein endothelium, it became necessary to determine whether it is possible to induce $\mathrm{AHH}$ activity in endothelial cells. We therefore exposed cultured endothelial cells to 3-methylcholanthrene and $\beta$-naphthoflavone in vitro. We found that $\mathrm{AHH}$ activity was increased 2 - to 10 -fold in cell cultures from five cords following such treatments. As shown in Figure 3, AHH activity increased as a function of the concentration of inducing agent present.

endothelial cells obtained from the same individual. $A$ compares activities from nonsmokers. A significant correlation $(r=0.823, p<0.01)$ is seen between placental and endothelial $\mathrm{AHH}$ activities. $B$ compares activities from smokers. Placental AHH activity is markedly increased and the correlation with endothelial AHH activity is lost $(r=-0.06)$.

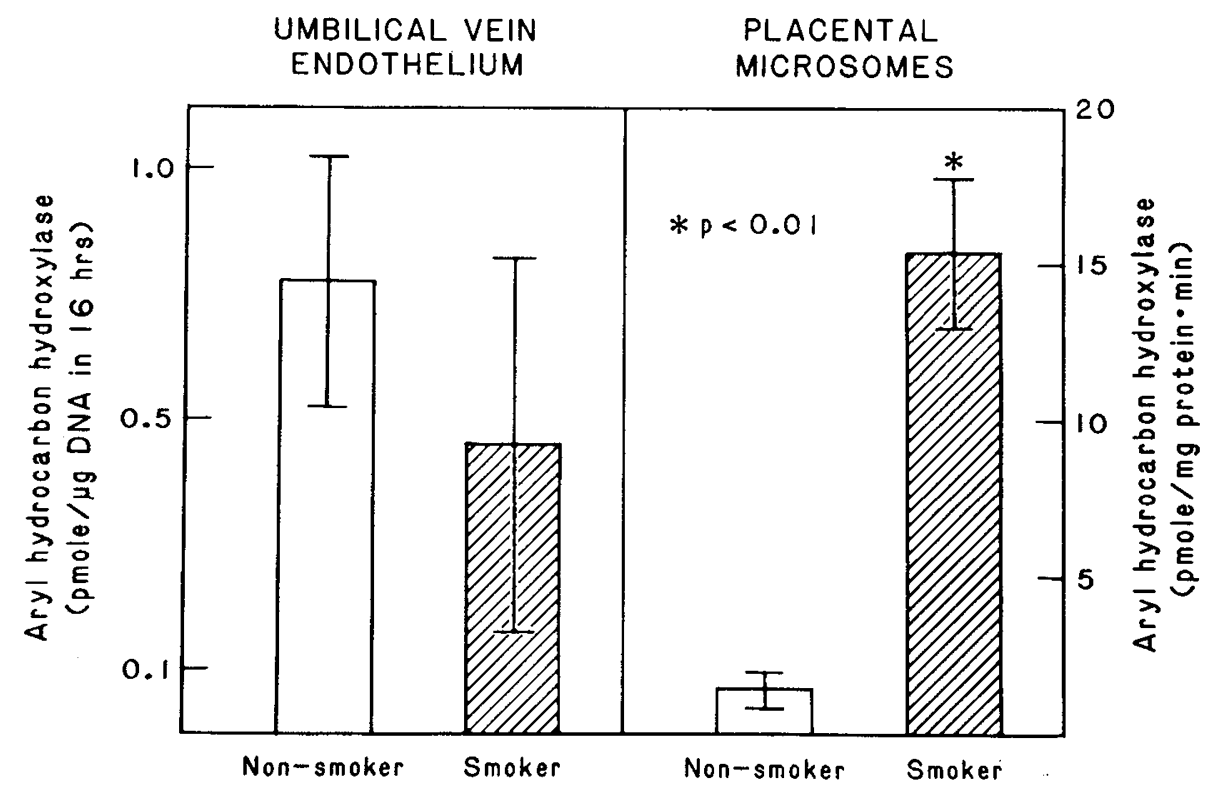

Fig. 2. Mean AHH activities in umbilical vein endothelium and placental microsomes. Mean AHH activity $(0.717 \pm 0.20$, nonsmokers versus $0.445 \pm 0.32 \mathrm{pmol} / \mu \mathrm{g}$ DNA in $16 \mathrm{~h}$, smokers) was not significantly different in endothelial cells harvested from umbilical vein from nonsmokers and smokers, but mean AHH activity in placental microsomes from smokers $(15.5 \pm 4.4 \mathrm{pmol} / \mathrm{mg}$ protein $/$ min $)$ was significantly higher than mean AHH activity in placental microsomes from nonsmokers $(0.09 \pm .02 \mathrm{pmol} / \mathrm{mg}$ protein $/ \mathrm{min})$. 


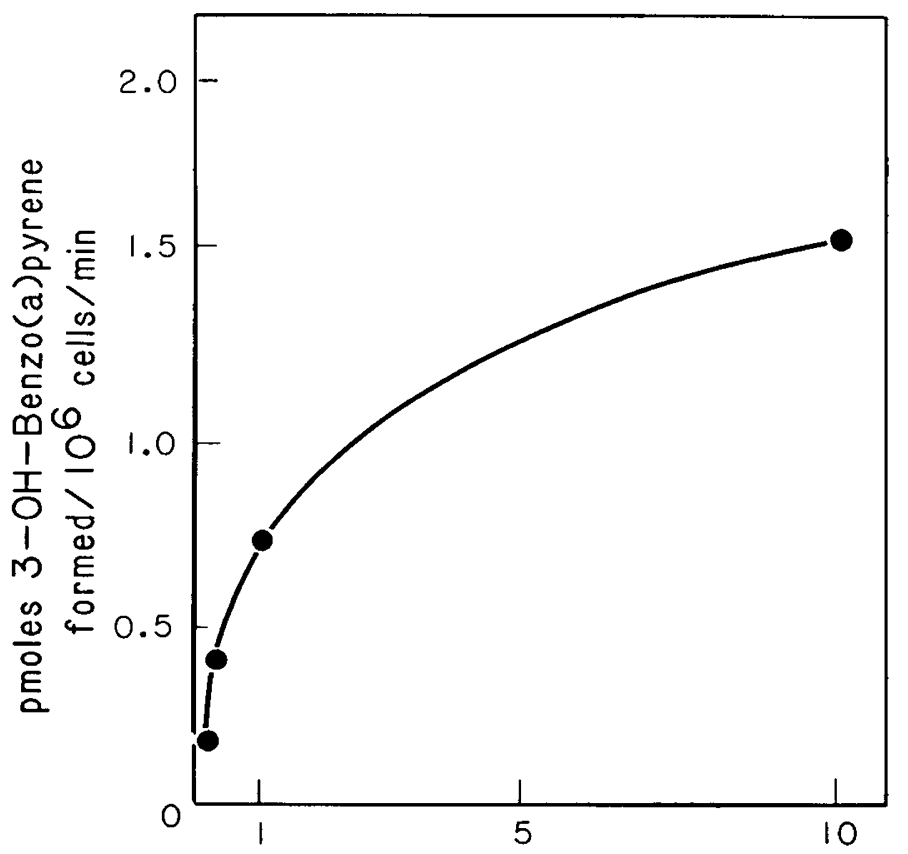

$\mu \mathrm{M}$ 3-methylcholanthrene

Fig. 3. Effect of PAH exposure on AHH activity in cultured human umbilical vein endothelial cells. Four primary cultures of endothelial cells from a single umbilical vein were exposed for $24 \mathrm{~h}$ to various concentrations of 3-methylcholanthrene. A dose-dependent increase in AHH activity was observed.

\section{DISCUSSION}

The results of this study indicate that while human umbilical vein endothelial cells are capable of increasing AHH activity in response to in vitro exposures to PAHs, AHH activity in umbilical vein endothelium does not increase in vivo under conditions which readily induce placental AHH activity. Therefore, since both of these tissues express fetal genotype, they appear to be exposed to markedly different toxicologic environments in smokers but not in nonsmokers.

These results are interesting because they represent the first correlation of AHH activities in paired placentas and fetal tissues from viable newborns. This approach allows the simultaneous evaluation of effects of maternal chemical exposures on tissues from maternal and fetal circulations. In addition, this approach can be applied to virtually any in utero xenobiotic exposure. In the case of maternal cigarette smoking, we have focused on responses of metabolic detoxication systems to PAHs and found that the tissue (placenta) which is perfused by the maternal circulation demonstrated AHH induction while the tissue (umbilical vein endothelium) which is perfused by the fetal circulation demonstrated no in utero $\mathrm{AHH}$ induction.

In previous studies, we and others have shown that placental AHH activity is quite sensitive to maternal smoke exposures (21, 22). In contrast, Pelkonen et al. (26) and Rifkind et al. (27) found that $\mathrm{AHH}$ levels in several tissues from medically aborted human fetuses do not appear to vary with maternal smoking. Our study confirms these findings and extends them by demonstrating lack of $\mathrm{AHH}$ induction in fetal tissue immediately distal to the induced placenta.

The mechanisms underlying these findings are unknown. However, the results are consistent with the hypothesis that increased placental AHH activity may participate in the clearance of PAHs from maternal circulation (6) and thereby lower the concentration of these compounds in fetal circulation. Such low PAH concentrations would then be insufficient to induce $\mathrm{AHH}$ activity in umbilical vein endothelium, consistent with the data in Figure 3. In support of this concept, Rowland et al. (28) have recently presented data suggesting that placental clearance of cortisol contributes to reduced levels of this potential teratogen in rat fetuses. This finding may explain why the rat is relatively resistant to the teratogenic actions of maternally administered cortisol.

Alternative explanations of our findings include the possibility that factors unique to fetal circulation may inhibit induction of AHH in fetal, but not placental, tissues. It is known, for instance, that a number of hormones may influence induction of $\mathrm{AHH}$ activity $(10,22)$. This possibility appears unlikely since none of these hormones are known to be specific to fetal circulation. Furthermore, since the placenta is also perfused with blood from the fetal circulation, such inhibitors might be expected to influence AHH induction in the placenta as well as umbilical vein. Another possibility is that the ability of specific organs to respond to PAH exposures may be under control of temporal genes (3). If this were the case here, some fetal tissues such as endothelium might be unable to respond to PAHs during gestation and early postnatal life while $\mathrm{AHH}$ activity in another tissue such as placenta might be induced by PAH exposure. Delayed postnatal development of metabolism of caffeine in human neonates (1) could reflect action of such temporal genes. This observation is particularly relevant because caffeine may be a substrate for AHH (2). While our data do not exclude this possibility, the ability of endothelial cells cultured from fetal circulation to respond to PAHs in vitro but not in vivo would require selective metabolic changes (loss of temporal gene effect) to occur in cells which are otherwise known to maintain many of their in vivo characteristics in tissue culture (7).

Our observation that maternal smoking induces AHH activity in placental, but not fetal, tissues may have important toxicologic consequences. Animal studies indicate that induction of $\mathrm{AHH}$ activity can contribute both to metabolic activation of xenobiotics and to their clearance (18). The relationship between the adverse effects of chemical exposures such as those associated with maternal smoking and xenobiotic metabolism by specific maternal and fetal tissues is likely to be very complex. Further understanding of the mechanisms responsible for differential effects of maternal smoking on placental and fetal tissues may provide better insight into the susceptibility of developing humans to toxic chemical exposures.

Acknowledgments. The authors wish to thank the nurses and delivery room staffs of University Hospital and Rose Medical Center, Denver, for their assistance in obtaining placental material for this study, and to acknowledge the encouragement and helpful advice of Dr. John Repine.

\section{REFERENCES}

1. Aldridge A, Aranda JV, Neims AH 1979 Caffeine metabolism in the developing human infant. Clin Pharmacol Ther 25:444

2. Aldridge A, Parsons WD, Neims AH 1977 Stimulation of caffeine metabolism in the rat by 3-methylcholanthrene. Life Sci 21:967

3. Atlas SA, Boobis AR, Felton JS, Thorgeirsson SS, Nebert DW 1977 Ontogenetic expression of polycyclic aromatic compound-inducible monooxygenase activities and forms of cytochrome P-450 in the rabbit. Evidence for temporal control and organ specificity of two genetic regulatory systems. J Biol Chem 252:4712

4. Ericson A, Kallen B, Westerholm P 1979 Cigarette smoking as an etiologic factor in cleft lip and palate. J Pediatr 135:348

5. Freudenthal RI, Jones PW (eds) 1976 Polynuclear Aromatic Hydrocarbons: Chemistry, Metabolism, and Carcinogenesis. Raven Press, New York

6. Gillette JR, Menard RH, Stripp B 1973 Active products of fetal drug metabolism. Clin Pharmacol Ther 14:680

7. Gimbrone MA 1976 Culture of vascular endothelium. Prog Hemostas Thromb 3:1

8. Gimbrone MA, Cotran RS, Folkman J 1974 Human vascular endothelial cells in culture. Growth and DNA synthesis. J Cell Biol 60:673

9. Gurtoo HL, Bejba N, Minowada J 1975 Properties, inducibility and improved method of analysis of aryl hydrocarbon hydroxylase in cultured human lymphocytes. Cancer Res 35:1235

10. Gurtoo HL, Parker NB 1976 Organ specificity of the sex dependent regulation of aryl hydrocarbon hydroxylase (AHH) in rat. Biochem Biophys Res Com- 
mun $72: 216$

11. Hoyer LW, de los Santos RR, Hoyer JR 1973 Antihemophilic factor antigen: localization in endothelial cells by immunofluorescent microscopy. J Clin Invest 52:2737

12. Jaffe EA, Hoyer LW, Nachman RL 1973 Synthesis of antihemophilic factor antigen by cultured human endothelial cells. J Clin Invest 52:2757

13. Jaffe EA, Nachman RL, Becker CG, Minick CR 1973 Culture of human endothelial cells derived from umbilical veins. Identification by morphologic and immunologic criteria. J Clin Invest 52:2745

14. Juchau MR 1971 Human placental hydroxylation of 3,4-benzopyrene during early gestation and at term. Toxicol Appl Pharmacol 18:665

15. Juchau MR, Namkung MJ, Jones AH, DiGiovanni J 1978 Biotransformation and bioactivation of 7,12-dimethylbenz(a)anthracine in human placental and fetal tissues. Drug Metab Dispos 6:273

16. Kline J, Stein Z, Susser M, Warburton D 1980 Environmental influences on early reproductive loss in a current New York City study. In: Porter IH, Hook EB (eds) Human Embryonic and Fetal Death, p 225. Academic Press, New York

17. Landesman-Dwyer S, Emanuel I 1979 Smoking during pregnancy. Teratology 19:119

18. Legraverend C, Harrison DE, Ruscetti FW, Nebert DW 1983 Bone marrow toxicity induced by oral benzo( $a$ )pyrene: protection resides at the level of the intestine and liver. Toxicol Appl Pharmacol, in press

19. Lowry OH, Rosebrough NJ, Farr AL, Randally RJ 1951 Protein measurement with the Folin phenol reagent. J Biol Chem 193:265

20. Manchester DK 1981 Range of environmentally responsive monooxygenase activities in human placental microsomes determined by direct fluorescence techniques. Biochem Pharmacol 30:757

21. Manchester DK, Jacoby EH 1981 Sensitivity of human placental monooxy- genase activity to maternal smoking. Clin Pharmacol Ther 30:687

22. Nebert DW, Gelboin HV 1969 The in vivo and in vitro induction of aryl hydrocarbon hydroxylase in mammalian cells of different species, tissues, strains and developmental and hormonal states. Arch Biochem Biophys 134:76

23. Nebert DW, Negishi M, Lang MA, Hjelmeland LM, Eisen HJ 1982 The Ah locus, a multigene family necessary for survival in a chemically adverse environment: comparison with the immune system. Adv Genet 21:1

24. Nebert SW, Winkler J, Gelboin HV 1969 Aryl hydrocarbon hydroxylase activity in human placenta from cigarette smoking and nonsmoking women. Cancer Res 29:1763

25. Paigen B, Gurtoo HL, Minowada J, Honten L, Vincent R, Paigen K, Parker NB, Ward E, Hayner NT 1977 Questionable relation of aryl hydrocarbon hydroxylase to lung-cancer risk. N Engl J Med 297:346

26. Pelkonen O, Arvela P, Karki NT 1971 3,4-Benzopyrene and $N$-methylaniline metabolizing enzymes in the immature human fetus and placenta. Acta Pharmacol Toxicol 30:385

27. Rifkind AB, Tseng L, Hirsch MB, Lauersen NH 1978 Aryl hydrocarbon hydroxylase activity and microsome cytochrome content of human fetal tissues. Cancer Res 38:1572

28. Rowland JM, Althans ZR, Slikker W, Hendrickx AG 1983 Comparative distribution and metabolism of triamcinolone acetonide and cortisol in the rat embryomaternal unit. Teratology 27:333

29. Vaught JB, Gurtoo HL, Parker NB, LeBoeuf R, Doctor G 1979 Effects of smoking on benzo( $a$ )pyrene metabolism by human placental microsomes Cancer Res 39:3177

30. Welch RM, Harrison YE, Conney AH, Poppers PJ, Finster M 1968 Cigarette smoking: stimulatory effect on metabolism of 3,4-benzopyrene by enzymes in human placenta. Science 160:541

\title{
Anticholeraic Effect of Methylated Casein in Rat Jejunum
}

\author{
M. PEYROT, J. F. DESJEUX, A. BEN MANSOUR, A. M. DUMONTIER, M. HAUTEFEUILLE \\ AND D. TOME
}

Unité de Recherche sur le Diabète et la Nutrition chez l'Enfant, INSERM U83, 75010, Paris, and INRA Centre de Recherche Agro-alimentaire Laboratoire de Technologie des Aliments des Animaux, 44072 Nantes Cedex, France

\begin{abstract}
To explore the antisecretory effect of methylated casein (MC) cholera toxin was placed in isolated jejunal loops, and in vivo water fluxes were measured $3 \mathrm{~h}$ later in the presence or absence of MC. Secretion was observed in the loops filled with Ringer's solution only, but net absorption was observed in all 10 loops to which MC was added. Its actions was evident within $20 \mathrm{~min}$, and was exerted directly on the luminal side of the epithelium. This response was dose-dependent and the antisecretory effect vanished after boiling $\mathrm{MC}$ and after ultrafiltration. In vitro, the antisecretory effect of $\mathrm{MC}$ consisted of reversing net $\mathrm{Na}$ and $\mathrm{Cl}$ fluxes from secretion to absorption $\left(\Delta J_{\text {net }}^{\mathrm{Na}}=\right.$ $6.18 \pm 1.25$ and $\Delta J_{\text {net }}^{\mathrm{Cl}}=5.10 \pm 1.66 \mu \mathrm{Eq} \cdot \mathrm{h}^{-1} \cdot \mathrm{cm}^{-2}$ ). This change was due to the enhancement of mucosal to serosal flux. Transepithelial potential difference and tissue conductance did not alter. Interestingly, MC did not interfere with intestinal function in the absence of stimulation by cholera toxin. In the presence of cholera toxin, MC and
\end{abstract}

Received October 6, 1983; accepted March 13, 1984.

Requests for reprints should be addressed to Dr. J. F. Desjeux, INSERM U83CHU Villemin, 10, Avenue de Verdun, 75010, Paris, France. glucose both stimulated ionic absorption by different mechanisms, MC stimulating neutral $\mathrm{NaCl}$ absorption, and glucose stimulating electrogenic $\mathrm{Na}$ absorption. MC did not alter basal adenylate cyclase activity but it inhibited the cholera toxin-stimulated increase in activity. The present results indicate that methylated casein inhibits water and electrolyte secretion induced by cholera toxin in rat jejunum. Its availability, low cost, and curative effect from the luminal side constitute compelling indications for further investigation. (Pediatr Res 18:1075-1079, 1984)

\section{Abbreviations}

CT, cholera toxin

$I_{s c}$, short circuit current $\left(\mu \mathrm{Eq} \cdot \mathbf{h}^{-1} \cdot \mathrm{cm}^{-2}\right)$

$P D$, transepithelial potential difference $(\mathrm{mV})$

$G$, tissue conductance $\left(\mathrm{mS} \cdot \mathrm{cm}^{-2}\right)$

$J_{m s}$, mucosal to serosal flux $\left(\mu \mathrm{Eq} \cdot \mathrm{h}^{-1} \cdot \mathrm{cm}^{-2}\right)$

$J_{s m}$, serosal to mucosal flux $\left(\mu \mathrm{Eq} \cdot \mathrm{h}^{-1} \cdot \mathrm{cm}^{-2}\right)$

MC, methylated casein 